\title{
Os 60 anos da SBPC/ML e a evolução da medicina laboratorial
}

A presente edição do JBPML chega a você junto com o $38^{\circ}$ Congresso Brasileiro de Patologia Clínica/Medicina Laboratorial, em Florianópolis, de 22 a 25 de setembro. É impossível deixar de sentir orgulho das realizações nesses 60 anos de entidade e nessas 38 edições do congresso. Em pouco mais de meio século de existência, a SBPC/ML tem oferecido os meios preferenciais para a atualização e o aprimoramento de milhares de profissionais de laboratório.

Essa liderança foi conquistada por um somatório de profissionais que, abnegadamente, têm cedido o seu tempo e o melhor de seus esforços em prol da medicina laboratorial. Contudo, se quisermos manter essa posição de liderança, temos que olhar para o futuro da especialidade. Precisamos estar atentos às tendências, mas também atuar, para que na concretização desse futuro estejam tijolos assentados por nós.

A medicina laboratorial cresce cada vez mais no que se refere à importância científica e na sua utilização para a tomada de decisões médicas, havendo quem aponte que o peso das informações geradas pelo setor de diagnóstico chega a ser de até 70\% nos processos cognitivos dos clínicos. Se assim é, torna-se pouco compreensível a profunda crise financeira e de identidade que, ao meu ver, ameaça o setor. Temos apenas dez programas de residência médica em patologia clínica no Brasil, um número estável desde há alguns anos. Os profissionais formados por eles têm abandonado, algumas vezes, a sua prática por não encontrarem a valorização e a colocação almejadas no mercado. Ou seja, corremos o risco de encolhimento, tanto em número absoluto quanto proporcional.

Mas crise é oportunidade. É chegado o momento para que os especialistas em medicina laboratorial se conscientizem do enorme valor científico e social de suas únicas e inigualáveis características e competências profissionais. É necessário que ocupemos todos os espaços possíveis, dando visibilidade à nossa atuação. Precisamos enterrar o paradigma quanto mais pedidos de exame, melhor e colaborar para a criação de um novo paradigma de atuação e remuneração, que privilegie a gestão racional dos recursos diagnósticos, para a melhoria da efetividade de assistência à saúde. Vamos fazer hoje a história que ainda será escrita. 